\title{
Testicular and seminal evaluation of goats fed hay Cenostigma pyramidale ${ }^{1}$
}

\author{
Maria V.B. Santos², Ana K.S. Cavalcante ${ }^{4}$, Juliana T.S.A. Macêdo ${ }^{3}$, \\ Marilúcia C. Santos ${ }^{2}$, Laiara F. Rocha ${ }^{5}$, Alessandro L. Machado ${ }^{5}$ \\ and Pedro M.O. Pedroso $2,3 *$ (D)
}

\begin{abstract}
Santos M.V.B., Cavalcante A.K.S., Macêdo J.T.S.A., Santos M.C., Rocha L.F., Machado A.L. \& Pedroso P.M.O. 2020. Testicular and seminal evaluation of goats fed hay Cenostigma pyramidale. Pesquisa Veterinária Brasileira 40(12):963-969. Laboratório de Patologia Veterinária, Universidade de Brasília, Campus Universitário Darcy Ribeiro, Via L4, Norte s/n, Brasília, DF 70910-970, Brazil. E-mail: pedrosovet@yahoo.com.br

This study aimed to assess the possible occurrence of reproductive changes in male goats associated with ingestion of Cenostigma pyramidale hay. Sixteen animals divided into two experimental groups, G1 and G2 (control group) were used. Animals in G1 received 2\% of forage, based on live weight (LW), composed of $100 \%$ of $C$. pyramidale, and animals in G2 received 2\% of Panicum maximum "Massai' grass hay, based on LW. Both groups received $1 \%$ of concentrated feed supplementation based on LW, along with mineralized salt and water ad libitum. The goats were subjected to weighing, testicular biometry, and semen and blood collection every 30 days. After 120 days, the animals were castrated and their testes were collected. Testicular measurements were performed and fragments were collected for histological processing to determine the gonadosomatic index (GSI), diameter of the seminiferous tubules, height of the germinal epithelium (HGE), volumetric proportion and volume of the testicular parenchyma components, total length of the seminiferous tubules, length of the seminiferous tubules per gram of testis, and leydigosomatic and tubulosomatic indexes. The data were evaluated for normality using the Student's $t$-test. Data with normal distribution were assessed using analysis of variance (ANOVA) and the non-parametric data were evaluated using the Kruskal-Wallis test, both at $5 \%$ probability. Statistically significant differences $(p<0.05)$ were observed for GSI (G1=0.48 \pm 0.08 and G2 $=0.34 \pm 0.09$ ) and HGE $(\mathrm{G} 1=52.95 \pm 2.99$ and $\mathrm{G} 2=.47 .63 \pm 2.67$ ) between treatments. Consumption of $C$. pyramidale hay increased LW and, consequently, testicular weight, contributing to high GSI. In conclusion, ingestion of C. pyramidale has no toxic effect on the testicular, seminal and histological parameters of goat testis. Due to its nutritional characteristics, consumption of this plant improves animal body development. Because C. pyramidale is adapted to semi-arid regions, it can be an alternative source of feed for goats during periods of shortage.
\end{abstract}

INDEX TERMS: Goats, hay, Cenostigma pyramidale, toxic plant, animal reproduction, male, testicle.

RESUMO.- [Avaliação testicular e seminal de caprinos alimentados com feno de Cenostigma pyramidale.] Para avaliar a possível ocorrência de alterações reprodutivas

\footnotetext{
${ }^{1}$ Received on June 22, 2020.

Accepted for publication on July 4, 2020

${ }^{2}$ Graduate Program in Animal Sciences in the Tropics (PPGCAT), Faculdade de Medicina Veterinária e Zootecnia, Universidade Federal da Bahia (UFBA), Av. Adhemar de Barros 500, Ondina, Salvador, BA 40170-110, Brazil.

${ }^{3}$ Laboratório de Patologia Veterinária, Universidade de Brasília (UnB), Campus Universitário Darcy Ribeiro, Via L4 Norte s/n, Brasília, DF 70910970, Brasil. *Corresponding author: pedrosovet@yahoo.com.br
}

em caprinos machos associado ao consumo de Cenostigma pyramidale, foram utilizados 16 animais divididos em dois grupos experimentais, G1 e G2 (grupo controle). Animais

\footnotetext{
${ }^{4}$ Laboratório de Estudos em Morfofunção Animal, Prédio Elismar V. Adorno (Biologia), Centro de Ciências Agrárias, Ambientais e Biológicas, Universidade Federal do Recôncavo da Bahia (UFRB), Rua Rui Barbosa 710, Campus Universitário, Cruz das Almas, BA 44380-000, Brazil.

${ }^{5}$ Hospital Universitário de Medina Veterinária, Centro de Ciências Agrárias, Ambientais e Biológicas, Universidade Federal do Recôncavo da Bahia (UFRB), Rua Rui Barbosa 710, Campus Universitário, Cruz das Almas, BA 44380-000, Brazil.
} 
pertencentes ao $\mathrm{G} 1$ receberam $2 \%$ de volumoso, com base no peso vivo (PV), constituído de $100 \%$ de $C$. pyramidale e o G2 receberam 2\%, com base no PV, de feno de Panicum maximum 'Massai'. Todos os grupos receberam 1\%, com base no PV, de suplementação concentrada, além de sal mineralizado e água ad libitum. A cada 30 dias os animais eram submetidos à pesagem, biometria testicular e coletas de sêmen. 0 sêmen foi avaliado quanto ao volume, turbilhonamento, vigor, motilidade, concentração espermática, defeitos maiores, menores e totais. Após 120 dias os animais foram castrados e os testículos coletados. Foram realizadas as mensurações testiculares e coletados fragmentos para o processamento histológico, para determinação do índice gonadossomático, diâmetro dos túbulos seminíferos, altura do epitélio germinativo, proporção volumétrica e volume dos componentes do parênquima testicular, comprimento total dos túbulos seminíferos, comprimento de túbulo seminífero por grama de testículo, índices leydigossomático e tubulossomático. Os dados foram avaliados quanto à normalidade pelo teste t de Student, os dados com distribuição normal foram analisados por análise de variância com $5 \%$ de probabilidade e os não paramétricos, pelo teste de Kruskal-Wallis, a 5\% de probabilidade. Houve diferenças significativas $(p<0,05)$ para índice gonadossomático $(\mathrm{G} 1=0,48 \pm 0,08$ e $\mathrm{G} 2=0,34 \pm 0,09)$ e altura do epitélio germinativo $(\mathrm{G} 1=52,95 \pm 2,99$ e $\mathrm{G} 2=47,63 \pm 2,67)$ entre os tratamentos. 0 feno de catingueira promoveu aumento no peso corporal e consequentemente maior peso testicular, o que contribui para elevação do IGS. Concluiu-se que o consumo da $C$. pyramidale não possui efeito tóxico sobre os parâmetros testiculares, seminais e histológicos do testículo dos caprinos e que a planta, por suas características nutricionais promoveu melhora no desenvolvimento corporal dos animais e por ser uma planta adaptada ao clima do semiárido, se constitui uma fonte alternativa de alimentação para esta categoria animal, durante períodos de escassez de alimento.

TERMOS DE INDEXAÇÃO: Caprinos, feno, Cenostigma pyramidale, planta tóxica, reprodução animal, caprino, testículo.

\section{INTRODUCTION}

Cenostigma pyramidale species, originally cataloged as Caesalpinia pyramidalis (Tul.) or Poincianella pyramidalis (Tul.) L.P. Queiroz (Flora do Brasil 2020), is popularly called "catingueira", "catinga-de-porco" or "pau-de-rato". These names are due to the unpleasant odor of their green leaves. It is a xerophilous, arboreal, medium-sized Fabaceae (Matias et al. 2017). C. pyramidale presents wide distribution in the Brazilian northeastern semi-arid region and is considered endemic in the Caatinga biome (Silva et al. 2009, Maia 2012). It is among the forage species most used by animals in the Caatinga (Araujo et al. 2010). Its hay has good nutritional value, presenting high protein concentrations (10.82\%) even in long periods of drought (Mendonça Jr. et al. 2008), which makes this species an important feed source for animals during the critical periods of forage scarcity in the dry season (Vieira et al. 2005).

In the Northeast region of Brazil, consumption of $C$. pyramidale is related to the occurrence of reproductive changes in female sheep and goats (Reis et al. 2016, Lopes et al. 2017). This plant is associated with one of the leading causes of abortion, embryonic mortality, and malformation in goats and sheep in the northeastern semi-arid region, being necessary to keep it out of the reach of females during pregnancy (Marcelino et al. 2017, Souza et al. 2018). Reproduction experiments conducted with goats (Reis et al. 2016) and sheep (Lopes et al. 2017) have proved that this plant causes congenital malformations, embryonic losses, and abortion and that the malformations observed in the animals studied were similar to those described by producers of the semi-arid region of the state of Bahia in cases of natural poisoning.

In the semi-arid region, where cases of natural poisoning have occurred (Marcelino et al. 2017), in addition to the toxic effects on females, many small ruminant producers reported that $C$. pyramidale also causes reproductive problems in male sheep and goats (Souza et al. 2018). Until then, reproductive changes due to consumption of $C$. pyramidale had only been proven in pregnant goats and sheep (Reis et al. 2016, Lopes et al. 2017), but toxic effects on the reproductive parameters in males had been observed.

This study aimed to carry out an experiment on pubescent male goats to determine whether $C$. pyramidale has a toxic effect on the reproductive system of male goats.

\section{MATERIALS AND METHODS}

The experiment was carried out in the premises of the "Setor de Caprinocultura" of the "Centro de Ciências Agrárias, Ambientais e Biológicas" of the "Universidade Federal do Recôncavo da Bahia" (CCAAB-UFRB) located in the municipality of Cruz das Almas, state of Bahia, Brazil. The project was approved by the Ethics Committee on the Use of Animals (CEUA) of UFRB under protocol no. 23007.000119352019-60.

Cenostigma pyramidale leaves were previously harvested manually from November to February 2019 in the Tupiaçú district (12³3'07.8" S; 39¹7'35.1" W), municipality of Cabaceiras do Paraguaçu, Recôncavo da Bahia. After drying in the shade for $6 \mathrm{~h}$ for three days, the leaves were crushed, weighed, and stored in plastic bags for daily supply to the animals.

A total of 16 male, crossbred goats with mean age $>1$ year and initial average live weight (LW) of $33 \mathrm{~kg}$ were used in the study. Initially, the animals were dewormed, vaccinated, and submitted to physical examination with measurement of heart and respiratory rates, ruminal movements and temperature, verification of mucous membranes and integrity of the common integument, palpation of lymph nodes to prove health, and andrological examination. All examinations were performed following the recommendations of the "Colégio Brasileiro de Reprodução Animal" (CBRA) and the animals underwent an adaptation period of 15 days. The goats were randomly assigned to two groups of eight animals each (G1 and G2). G1 was fed $1 \%$ concentrated supplementation (CS) based on LW and $2 \%$ roughage based exclusively on $C$. pyramidale hay. In G2, the feed consisted of $1 \%$ CS based on LW and 2\% roughage based on Panicum maximum 'Massai' hay. Both groups received CS prepared with corn and soy bran enriched with vitamins and minerals, in addition to mineralized salt and water ad libitum. The hay was homogenized with the CS and ingested spontaneously.

Samples of $C$. pyramidale and Massai grass hay were sent for bromatological analysis at the "Laboratório de Nutrição Animal" of UFRB. The bromatological composition of the diets was prepared according to the Association of Official Analytical Chemists (AOAC, 1992) to determine the levels of dry matter (DM), mineral matter $(\mathrm{MM})$, and crude protein (CP). Determination of neutral detergent 
fiber (NDF) and acid-detergent fiber (ADF) was carried out according to Van Soest et al. (1991).

Every 30 days, the animals were weighed individually and testicular biometry (TB) was performed, always by the same operator. The scrotal perimeter (SP) was measured using a measuring tape. The length, width, and thickness of the right and left testes were measured using a caliper. Testicular consistency was assessed through qualitative analysis by palpation and was classified as fibro-elastic (normal), firm, or flaccid (abnormal). The animals were submitted to semen collection every 30 days since the beginning of plant supply using the artificial vagina method and a female in estrus as a mannequin. After obtaining the ejaculate, the following seminal characteristics were evaluated: volume of the ejaculate, seminal color and aspect, and semen swirl, vigor, motility and concentration, as well as semen morphology including major and minor defects.

After 120 days of supplying the diets to each group, the animals were submitted to bilateral surgical orchiectomy. After removal, the testes were weighed, measured, and dissected. Tissue fragments were collected and fixed in $10 \%$ buffered formaldehyde. Subsequently, testicular fragments were processed routinely by histological techniques, stained with hematoxylin-eosin (HE), and analyzed by optical microscopy.

The following testicular morphometric parameters were analyzed: right and left testicular weight, gonadosomatic index (GSI), diameter of seminiferous tubules, height of the germinal epithelium (HGE), volumetric proportion of the components of the testicular parenchyma, total length of seminiferous tubules, length of seminiferous tubule per gram of testis, and leydigosomatic and tubulosomatic indexes.

The tubular diameter and height of the epithelium were measured using a 10x micrometric eyepiece and a 10x objective under an optical microscope. Twenty cross-sections chosen at random through horizontal scanning - the ones with the most circular contour - were measured and had their mean determined for each animal.

Height of the epithelium was obtained in the same tubules used to measure the diameter, considering the epithelial thickness from the basal membrane to the luminal border. Two measurements from each cross-section were obtained, referring to the two contralateral points. The mean between the two measurements was considered a representative measure.

The volumetric proportion data of the testicular parenchyma components were obtained using a graticule with 408 intersections considered as points, with 400x magnification. Ten random fields were evaluated and, for each animal, evaluation of the coincident points was performed on the different constituent elements of the testicular parenchyma. Approximately 2,040 points were counted per animal. The following testicular parenchyma components were recorded: seminiferous tubule (tunica propria, seminiferous epithelium, and tubular lumen), Leydig interstitial cells, blood vessels, and connective tissue.

The total length of seminiferous tubules was obtained using the formula (França et al. 2000):

$$
\text { LST }=\frac{v s t}{\pi r^{2}}
$$

where, LST = total length of seminiferous tubules, VST = total volume of seminiferous tubules, previously calculated by the volumetric proportion of seminiferous tubules in the testicular volume, and $\mathrm{r}^{2}=$ base area corresponding to the cross-section area of the seminiferous tubule, considering the radius ( $r$ ) as half the average diameter.
The final result referring to the total tubule length was expressed in meters for each animal. The GSI, which represents the percentage of body mass allocated in the testis, was calculated from the average weight of the two tests divided by the live weight. The leydigosomatic and tubulosomatic indexes represent the percentage of body mass allocated in the Leydig cells and seminiferous tubules. The percentage of testicular parenchyma of the Leydig cells and seminiferous tubules was calculated using the GSI.

All parameters were initially tested for normality using the Student's $t$-test. THe parameters with normal distribution were assessed using analysis of variance (ANOVA) and the non-parametric data were evaluated by the Kruskal-Wallis test, both at $5 \%$ probability.

\section{RESULTS}

A sample of Massai grass hay supplied to the animals showed percentages of CP, NDF, and ADF of 3.02, 84.12 and 47.24, respectively, whereas a sample of Cenostigma pyramidale hay showed percentages of CP, NDF, and ADF of 10.82, 63.2, and $28.09 \%$, respectively (Table 1 ).

Regarding the testicular biometric parameters and LW of goats in the evaluated periods, no differences were found between the groups ( $p>0.05)$, and it was observed that the averages were close in all parameters studied, except for live weight, which presented variation between the periods. In both groups, SP varied with LW and increased as a result of it. In G1, in 60 days, the mean SP was $20.1 \mathrm{~cm}$ with $26.6 \mathrm{~kg}$ LW, and in 120 days, the mean SP was $22.6 \mathrm{~cm}$ with $36.2 \mathrm{~kg}$ LW. In G2, the mean SP values were $21.3 \mathrm{~cm}$ over 60 days with $28.5 \mathrm{~kg} \mathrm{LW}$ and $33.9 \mathrm{~cm}$ over 120 days with a $35.5 \mathrm{~kg}$ LW (Table 2).

Testicular consistency was the same in both experimental groups $(p>0.05)$. In all periods evaluated, the testicles were tenso-elastic, which indicates normal testicular constitution.

As for the seminal aspect characteristic, in all evaluations, color was uniform with predominance of yellow ivory, and the consistency varied between creamy and milky.

When considering the semen characteristics in the evaluated periods, it was observed that G1 and G2 were similar, and that there was no difference ( $p>0.05)$ in all the variables analyzed, presenting parameters adequate for the goat species. However, in the first semen collection both in G1 and G2, minor defects corresponded to 23.21 and $21.85 \%$ and total defects accounted for 29.28 and $27.85 \%$, respectively (Table 3 ).

Table 4 shows that there was statistically significant difference between the groups for the characteristics of the gonadosomatic index (GSI) and HGE $(p<0.05)$, in which G1 showed higher values than G2. For GSI, G1 showed $0.48 \%$, while G2 presented $0.34 \%$, and for HGE, the values were 52.95 and $47.63 \mu \mathrm{m}$ for G1 and G2, respectively. No effect of the

Table 1. Chemical composition of the diets supplied to the animals

\begin{tabular}{lcc}
\hline \multicolumn{1}{c}{ Parameters } & $\begin{array}{c}\text { Cenostigma } \\
\text { pyramidale }\end{array}$ & $\begin{array}{c}\text { Panicum } \\
\text { maximum }\end{array}$ \\
\hline Dry matter (\%) & 91.06 & 91.07 \\
Mineral matter (\%) & 2.70 & 7.3 \\
Crude protein (\%) & 10.82 & 3.02 \\
Neutral detergent fiber (\%) & 63.62 & 84.12 \\
Acid-detergent fiber (\%) & 28.09 & 47.24
\end{tabular}


diets provided was found for the other parameters $(p>0.05)$. However, testicular weight was greater in G1 compared with G2, with mean values of 87 and $63 \mathrm{~g}$, respectively.

When considering the volumetric proportions of the testicular parenchyma components, no treatment was effective on the constituents of the seminiferous tubules or the intertubular tissue ( $p>0.05)$. However, higher proportions of seminiferous tubules compared with intertubular tissue were observed in both experimental groups (Table 5).

In the histological study, no changes were observed after ingestion of $C$. pyramidale by goats for 120 days in both groups.

\section{DISCUSSION}

Cenostigma pyramidale has been proved to be toxic for goats and sheep, with effects observed in the organogenesis phase (Reis et al. 2016, Souza et al. 2018). However, results of this study demonstrated that its consumption for 120 days by pubescent male goats did not result in toxicity to the reproductive system, not causing changes in the gametes. Because this plant presents good nutritional value with adequate protein concentrations, it constituted an excellent feed source for the animals.

Testicular measurements are considered as parameters in the evaluation of goat semen production. The scrotal perimeter (SP) is an excellent parameter to evaluate the size of the testes and the semen production capacity of goats, thus serving as a way to select a breeder for the herd. This variable does not dependent on breed or climate, but it has a close relationship with age and LW (Almeida et al. 2010). In the present study, the increase in LW positively influenced the SP indexes, and these were presented according to age and LW for both experimental groups. A similar finding was described by Souza et al. (2011) when studying Anglo-Nubian goats aged from 20-44 weeks, who observed average SP values of 21.1 and $25.5 \mathrm{~cm}$, and LW values of 25.75 and 43.6 $\mathrm{kg}$, respectively, and by Rodrigues (2010) in Alpine goats at 12 months of age, with a LW of $27 \mathrm{~kg}$ and SP of $22 \mathrm{~cm}$.

The ejaculate volume of goats varies from 0.1 to $1.5 \mathrm{~mL}$ according to the CBRA (2013). For this variable, the means of experimental groups ranged from 0.4 to $0.7 \mathrm{~mL}$ and 0.2 to $0.9 \mathrm{~mL}$ in G1 and G2, respectively. This range indicates good functioning of the accessory sexual glands, associated with androgen production and libido of the animal, reflecting in seminal volume increase.

Greater development of the testes was observed in both experimental groups overtime. Growth of the testicular parenchyma and the consequent expansion of the diameter of the seminiferous tubules, as a result of proliferation of the germ cells and differentiation of the Sertoli cells, provided an increase in semen concentration. According to Aguiar et al. (2006), semen concentration gradually increases with advancing age, since it is directly related to development of the seminiferous tubules, as semen remain inactive until puberty when they start to divide and proliferate.

Increase in the percentages of minor and total defects at baseline occurred as a result of the high frequency of bent tail

Table 2. Testicular biometrics and body weight of goats in the different periods of supply of Cenostigma pyramidale

\begin{tabular}{|c|c|c|c|c|c|c|c|c|c|}
\hline Group & Period (days) & $\mathrm{SP}(\mathrm{cm})$ & $\begin{array}{l}\text { Length LT } \\
(\mathrm{cm})\end{array}$ & $\begin{array}{l}\text { Length RT } \\
(\mathrm{cm})\end{array}$ & $\begin{array}{l}\text { Width LT } \\
(\mathrm{cm})\end{array}$ & $\begin{array}{l}\text { Width RT } \\
(\mathrm{cm})\end{array}$ & $\begin{array}{c}\text { Thickness LT } \\
(\mathrm{cm})\end{array}$ & $\begin{array}{c}\text { Thickness RT } \\
(\mathrm{cm})\end{array}$ & BW (kg) \\
\hline \multirow[t]{5}{*}{ G1 } & 0 & $21.9 \pm 1.9$ & $6.7 \pm 0.8$ & $6.8 \pm 0.9$ & $3.8 \pm 0.4$ & $3.8 \pm 0.4$ & $4.3 \pm 0.5$ & $4.3 \pm 0.4$ & $34.1 \pm 6.6$ \\
\hline & 30 & $21.1 \pm 2.1$ & $6.4 \pm 0.9$ & $6.6 \pm 0.9$ & $3.9 \pm 0.5$ & $3.8 \pm 0.3$ & $4.3 \pm 0.7$ & $4.3 \pm 0.6$ & $34.3 \pm 9.5$ \\
\hline & 60 & $20.1 \pm 2.9$ & $6.2 \pm 0.9$ & $6.3 \pm 0.8$ & $3.5 \pm 0.6$ & $3.6 \pm 0.5$ & $4.3 \pm 0.6$ & $4.2 \pm 0.6$ & $26.6 \pm 6.5$ \\
\hline & 90 & $22.1 \pm 2.1$ & $6.5 \pm 0.6$ & $6.6 \pm 0.6$ & $4.0 \pm 0.4$ & $4.0 \pm 0.4$ & $4.1 \pm 0.7$ & $4.2 \pm 0.8$ & $28.0 \pm 6.6$ \\
\hline & 120 & $22.6 \pm 2.1$ & $6.7 \pm 0.9$ & $6.8 \pm 0.8$ & $4.3 \pm 0.38$ & $4.3 \pm 0.3$ & $4.2 \pm 0.6$ & $4.2 \pm 0.7$ & $36.2 \pm 7.3$ \\
\hline \multirow[t]{5}{*}{ G2 } & 0 & $21.8 \pm 2.5$ & $6.0 \pm 0.8$ & $6.2 \pm 0.8$ & $3.8 \pm 0.4$ & $3.7 \pm 0.3$ & $4.1 \pm 0.6$ & $4.0 \pm 0.6$ & $33.6 \pm 8.1$ \\
\hline & 30 & $21.3 \pm 2.6$ & $6.2 \pm 0.8$ & $6.2 \pm 0.8$ & $3.7 \pm 0.5$ & $3.7 \pm 0.6$ & $4.0 \pm 0.7$ & $4.0 \pm 0.7$ & $34.8 \pm 7.0$ \\
\hline & 60 & $21.3 \pm 3.2$ & $6.2 \pm 1.0$ & $6.3 \pm 1.0$ & $3.9 \pm 0.6$ & $3.9 \pm 0.7$ & $4.3 \pm 0.6$ & $4.2 \pm 0.7$ & $28.5 \pm 8.2$ \\
\hline & 90 & $21.6 \pm 3.7$ & $6.2 \pm 0.9$ & $6.2 \pm 1.0$ & $3.9 \pm 0.6$ & $3.8 \pm 0.6$ & $4.3 \pm 1.1$ & $4.3 \pm 1.2$ & $27.8 \pm 8.9$ \\
\hline & 120 & $23.9 \pm 3.6$ & $6.2 \pm 1.0$ & $6.1 \pm 1.0$ & $4.4 \pm 0.6$ & $4.5 \pm 0.6$ & $4.2 \pm 0.7$ & $4.2 \pm 0.8$ & $35.5 \pm 7.1$ \\
\hline
\end{tabular}

G1 = goats fed C. pyramidale hay, G2 = control group, $\mathrm{SP}=$ scrotal perimeter, BW = body weight, $\mathrm{RT}=$ right testis, $\mathrm{LT}=$ left testis.

Table 3. Seminal physical and morphological parameters of goats in the different periods of supply of Cenostigma pyramidale

\begin{tabular}{|c|c|c|c|c|c|c|c|c|c|}
\hline Group & Period & $\begin{array}{c}\text { Volume } \\
(\mathrm{mL})\end{array}$ & $\begin{array}{l}\text { Swirl } \\
(0-5)\end{array}$ & $\begin{array}{l}\text { Vigor } \\
(0-5)\end{array}$ & Motility (\%) & $\begin{array}{c}\text { Conc. (x109/ } \\
\text { mL) }\end{array}$ & DMaj (\%) & DMin (\%) & DTot (\%) \\
\hline \multirow[t]{5}{*}{ G1 } & 0 & $0.7 \pm 0.3$ & $3.6 \pm 0.4$ & $3.4 \pm 0.4$ & $81.4 \pm 6.9$ & $3.6 \pm 1.2$ & $6.1 \pm 3.1$ & $23.2 \pm 8.1$ & $29.3 \pm 7.4$ \\
\hline & 30 & $0.5 \pm 0.3$ & $2.9 \pm 1.4$ & $3.3 \pm 1.6$ & $73.0 \pm 29.9$ & $4.7 \pm 1.4$ & $2.2 \pm 1.6$ & $15.7 \pm 5.7$ & $17.9 \pm 6.0$ \\
\hline & 60 & $0.7 \pm 0.6$ & $3.3 \pm 1.2$ & $4.2 \pm 0.8$ & $85.0 \pm 15.2$ & $4.7 \pm 1.8$ & $2.9 \pm 2.4$ & $12.3 \pm 3.5$ & $15.2 \pm 5.3$ \\
\hline & 90 & $0.4 \pm 0.3$ & $3.7 \pm 0.8$ & $3.5 \pm 0.6$ & $82.0 \pm 4.5$ & $4.2 \pm 1.6$ & $1.6 \pm 0.8$ & $11.6 \pm 3.8$ & $13.3 \pm 3.3$ \\
\hline & 120 & $0.7 \pm 0.3$ & $3.0 \pm 1.6$ & $3.8 \pm 1.2$ & $78.3 \pm 17.2$ & $4.4 \pm 1.4$ & $3.3 \pm 0.5$ & $8.5 \pm 3.0$ & $11.0 \pm 2.9$ \\
\hline \multirow[t]{5}{*}{ G2 } & 0 & $0.8 \pm 0.4$ & $3.3 \pm 1.0$ & $3.0 \pm 0.8$ & $74.3 \pm 12.7$ & $3.2 \pm 0.8$ & $6.0 \pm 1.9$ & $21.9 \pm 9.8$ & $27.9 \pm 9.3$ \\
\hline & 30 & $0.4 \pm 0.3$ & $3.0 \pm 1.4$ & $3.2 \pm 1.3$ & $71.4 \pm 16.5$ & $4.0 \pm 1.4$ & $2.4 \pm 3.2$ & $9.3 \pm 4.4$ & $11.6 \pm 5.8$ \\
\hline & 60 & $0.8 \pm 0.6$ & $3.0 \pm 1.3$ & $3.3 \pm 1.4$ & $75.7 \pm 19.0$ & $4.2 \pm 2.5$ & $2.6 \pm 1.5$ & $12.0 \pm 4.9$ & $14.6 \pm 5.7$ \\
\hline & 90 & $0.2 \pm 0.1$ & $4.0 \pm 0.6$ & $3.9 \pm 0.4$ & $77.9 \pm 8.1$ & $4.9 \pm 0.9$ & $1.4 \pm 1.2$ & $8.9 \pm 4.1$ & $10.3 \pm 5.1$ \\
\hline & 120 & $0.9 \pm 0.5$ & $4.1 \pm 0.7$ & $4.9 \pm 0.4$ & $92.9 \pm 7.6$ & $5.0 \pm 0.9$ & $3.9 \pm 1.2$ & $8.2 \pm 2.3$ & $12.1 \pm 2.7$ \\
\hline
\end{tabular}

$\overline{\text { G1 }=\text { goats fed C. pyramidale hay, G2 = control group }}$, Conc. = concentration, DMaj $=$ major defects, DMin $=$ minor defects, DTot $=$ total defects. 
and distal cytoplasmic gout pathologies in both experimental groups. These defects were considered less important. These values stabilized after 30 days.

Semen defects with a bent or coiled tail can be caused by failures in thermoregulation, testicular degeneration, hypoosmotic conditions, failures in epididymal transit, or thermal shock, especially when using cold formaldehyde to fix semen (Souza et al. 2011). Distal cytoplasmic gout and tail pathologies are associated with immaturity or reproductive rest (Arruda et al. 2015). Thus, these data corroborate the percentage of pathologies found in the present study, justifying that they were possibly caused by sexual rest and heat stress.

A relationship between testicular and live weight was observed in both groups. The animals in G1 presented higher means than those in G2. In domestic animals, testicular weight varies between species. It is determined by several factors, such as establishment of semen activity, increase in the population of germ cells, and number of Sertoli cells, directly affecting semen production. According to Rodrigues (2010), there is a fast growth of testicular weight between four and six months of age due to the accelerated growth of the tubular diameter and length and, consequently, of the volume of the seminiferous tubules in the testicular parenchyma. After this period, testicular growth stabilizes. Variations in testicular weight of goats at other ages are attributed to genetic characteristics and environmental, feeding and handling conditions.

The GSI corresponds to the somatic investment in gonadal mass, being a parameter that represents semen production

Table 4. Testicular weight and testicular morphometric parameters of goats fed Cenostigma pyramidale hay

\begin{tabular}{lcc}
\hline \multicolumn{1}{c}{ Parameters } & G1 & G2 \\
\hline Testicular weight $(\mathrm{g})$ & $87.00 \pm 20.40$ & $63.00 \pm 26.67$ \\
GSI $(\%)$ & $0.48 \pm 0.08^{*}$ & $0.34 \pm 0.09$ \\
DST $(\mu \mathrm{m})$ & $226.61 \pm 7.96$ & $225.25 \pm 5.96$ \\
LD $(\mu \mathrm{m})$ & $107.86 \pm 11.38$ & $118.75 \pm 15.89$ \\
HGE $(\mu \mathrm{m})$ & $52.95 \pm 2.99^{*}$ & $47.63 \pm 2.67$ \\
LSI $(\%)$ & $0.0009 \pm 0.0005$ & $0.0007 \pm 0.0003$ \\
TSI $(\%)$ & $0.2755 \pm 0.0481$ & $0.2836 \pm 0.0634$ \\
LST $(\mathrm{m})$ & $2.407 .34 \pm 144.81$ & $2.442 .32 \pm 139.52$ \\
LGT $(\mathrm{m} / \mathrm{g})$ & $14.52 \pm 3.56$ & $22.24 \pm 8.76$
\end{tabular}

* Statistical difference $(p>0.05) ; \mathrm{G} 1=$ goats fed $C$. pyramidale hay, $\mathrm{G} 2$ = control group, $\mathrm{GSI}=$ gonadosomatic index, $\mathrm{DST}=$ diameter of seminiferous tubules, $\mathrm{LD}=$ lumen diameter, $\mathrm{HGE}=$ height of the germinal epithelium, LSI = leydigosomatic index, TSI = tubulosomatic index, LST = total length of seminiferous tubules, LGT = total length of seminiferous tubules per gram of testis.

Table 5. Volumetric proportion of the components of the testicular parenchyma of goats fed Cenostigma pyramidale hay

\begin{tabular}{lcc}
\hline \multicolumn{1}{c}{ Parameters (\%) } & G1 & G2 \\
\hline Lumen & $21.55 \pm 4.28$ & $19.87 \pm 3.23$ \\
Germinal epithelium & $73.89 \pm 3.28$ & $75.65 \pm 3.11$ \\
Basement membrane & $1.37 \pm 0.40$ & $1.58 \pm 0.53$ \\
Connective tissue & $2.62 \pm 1.78$ & $2.38 \pm 1.00$ \\
Leydig cells & $0.44 \pm 0.23$ & $0.42 \pm 0.23$ \\
Blood vessel & $0.14 \pm 0.5$ & $0.10 \pm 0.3$
\end{tabular}

G1 = goats fed C. pyramidale hay, G2 = control group. from the high correlation between semen volume and testicular weight. The animals in G1 showed a higher percentage of LW allocated in the testes. This variable has a high correlation with live and testicular weights, and these averages were higher in G1 than in G2, which influenced the GSI found. Van Soest (1994) recommend at least 6-8\% CP for rumen microbial fermentation efficiency, which may explain the higher LW verified G1 compared with G2. Cenostigma pyramidale hay exhibited a percentage of $10.82 \%$ of $C P$, higher than the recommended to meet the demand for nutrients, providing balance in feed use by ruminal microorganisms compared with Massai grass hay, with a CP percentage of $3.02 \%$. According to Urbano et al. (2015), reducing CP consumption negatively influences weight gain and carcass quality. Also, higher percentages of NDF were observed in Massai grass hay compared with $C$. pyramidale hay. According to Ribeiro et al. (2020), increased NDF levels harms feeding efficiency and reduces weight gain. Therefore, ingestion of $C$. pyramidale hay promoted an increase in LW and, consequently, greater testicular weight, which contributed to increasing the GSI.

Diameter measurements of the seminiferous tubules indicate spermatogenic activity, testicular function, and development of the germinal epithelium. There are significant variations in these dimensions among the different domestic species (França \& Godinho 2003). In this study, this measure was similar to that observed by Rodrigues (2010) for Alpine goats at one year of age, who found an average of $228 \mu \mathrm{m}$. A higher value was reported by Mohammed et al. (2011) in goats at two years of age, who reported an average of $258 \mu \mathrm{m}$. According to Morais et al. (2012), variation in the tubular diameter of mammals can be observed between different breeds, strains, and mating systems, remaining relatively constant in nonseasonal and sexually mature animals. According to Avelar et al. (2010), the diameter of the seminiferous tubules depends on the tubular lumen size and on the total number of cells per cross-section of the seminiferous tubule. Various factors collaborate in the tubular diameter, such as the number of layers of germ cells and the efficiency and secretion of fluids by the Sertoli cells, which influence the tubular lumen size.

The morphometric study of the testes showed that the animals fed $C$. pyramidale hay presented higher means for the height of the seminiferous epithelium. According to Hoshino et al. (2002) this variable is higher in adult animals. This finding occurs because of the greater stimulus of mitosis and greater spermatogenesis, generating an extensive epithelium resulting from the larger number of cells.

Studies conducted with $C$. pyramidale extract revealed its cytotoxic effect through the Allium cepa test, which showed higher mitotic indices as a consequence of increased cell division and proliferation (Queiroz et al. 2018). Therefore, the height of seminiferous epithelium in G1 was possibly stimulated by ingestion of the plant, which acted on the germ cells, increasing cell division. However, it is not possible to conclude that the components of $C$. pyramidale were cytotoxic, which requires more detailed studies.

Mean proportional values referring to the testicular parenchyma components revealed similarity to the seminiferous tubules and intertubular tissue between the experimental groups, demonstrating that consumption of $C$. pyramidale did not alter the composition of the testicular parenchyma. Concerning the seminiferous tubules, the animals in this 
study showed proportional values slightly above the average of most species, which vary between 60 and $90 \%$ (Russell et al. 1993). This fact is directly associated with the volumetric proportion occupied by the testis intertubular tissue, for which the animals in this study showed greater investment in seminiferous tubules compared with their intertubular space.

The tubulosomatic index is associated with volume of the seminiferous tubules in the testis and with animal LW. This parameter proposes quantifying the percentage of body investment in seminiferous tubules, allowing intra- and interspecific comparison between animals of different body sizes (Leite et al. 2006). A higher percentage than that observed in both experimental groups was described by Rodrigues (2010) in Alpine goats at 12 months of age with an average LW of $27 \mathrm{~kg}$, where tubulosomatic index was $0.36 \%$. This difference can be explained by the higher LW of the animals of the present study.

Variations in diameter and volume of the seminiferous tubules in the testicular parenchyma are reflected in the LST value variation. Thus, the larger the diameter of the seminiferous tubules, the smaller the LST value. The goats in G1 and G2 showed values higher than those of the crossbred goats studied by Lents et al. (2018), which presented LST of $1,769.48 \mathrm{~m}$ and LGT of $13.06 \mathrm{~m} / \mathrm{g}$. This difference occurred because of the greater tubular diameter and volume values used to obtain these results.

\section{CONCLUSION}

Ingestion of Cenostigma pyramidale has no toxic effect on the testicular, seminal and histological parameters of goat testis. Due to its nutritional characteristics, consumption of this plant improves animal body development. Because $C$. pyramidale is adapted to semi-arid regions, it can be an alternative source of feed for goats during periods of shortage.

Acknowledgments.- The first author would like to thank the "Fundação de Amparo à Pesquisa do Estado da Bahia" (FAPESB) for the grant of the master's scholarship. This study was supported by "Instituto Nacional de Ciência e Tecnologia”, "Conselho Nacional de Desenvolvimento Científico e Tecnológico" (INCT-CNPq) for the Control of Poisoning by Plants (Proc. No. 573534/2008-0).

Conflict of interest statement.- The authors declare having no competing interests.

\section{REFERENCES}

Aguiar G.V., Araújo A.A. \& Moura A.A.A. 2006. Desenvolvimento testicular, espermatogênese e concentrações hormonais em touros Angus. Revta Bras. Zootec. 35(4supl.):1629-1638. <https://dx.doi.org/10.1590/S151635982006000600008>

Almeida M.M., Machado Jr A.A.N., Ambrósio C.E., Menezes C.E., Righi D.A., Nascimento I.M.R. \& Carvalho M.A.M. 2010. Influência do grau de bipartição escrotal sobre parâmetros reprodutivos de caprinos. Pesq. Vet. Bras. 30(4):345-350.<https://dx.doi.org/10.1590/S0100-736X2010000400011>

AOAC 1992. Official Methods of Analysis. 12nd ed. Association of Official Analytical Chemists, Washington. 1094p.

Araujo K.D., Dantas R.T., Andrade A.P., Parente H.N. \& Silva E.E. 2010. Uso de espécies da caatinga na alimentação de rebanhos no município de São João do Cariri-PB. RA'E GA 20:157-171.
Arruda R.P., Celeghini E.C.C., Garcia A.R., Santos G.C., Leite T.G., Oliveira L.Z., Lançoni R. \& Rodrigues M.P. 2015. Morfologia espermática de touros: interpretação e impacto na fertilidade. Revta Bras. Reprod. Anim. 39(1):47-60.

Avelar G.F., Oliveira C.F.A., Soares J.M., Silva I.J., Dobrinski I., Hess R.A. \& França L.R. 2010. Postnatal somatic cell proliferation and seminiferous tubule maturation in pigs: a non-random event. Theriogenology 74(1):11-23. <https://dx.doi.org/10.1016/j.theriogenology.2009.12.014><PMid:20189235>

CBRA 2013. Manual para Exame Andrológico e Avaliação de Sêmen Animal. 3 a ed. Colégio Brasileiro de Reprodução Animal, Belo Horizonte. 87p.

Flora do Brasil 2020. Jardim Botânico do Rio de Janeiro. Available at $<$ http://floradobrasil.jbrj.gov.br> Accessed on Jun., 2019. (in Construction)

França L.R. \& Godinho C.L. 2003. Testis morphometry, seminiferous epithelium cycle length, and daily sperm production in domestic cats (Felis catus). Biol. Reprod. 68(5):1554-1561.<https://dx.doi.org/10.1095/ biolreprod.102.010652><PMid:12606460>

França L.R., Silva Jr V.A., Chiarinigarcia H., Garcia S.K. \& Debeljuk L. 2000. Cell proliferation and hormonal changes during postnatal development of the testis in the pig. Biol. Reprod. 63(6):1629-1636. <https://dx.doi.org/10.1095/biolreprod63.6.1629> <PMid:11090429>

Hoshino P., Nakaghi L.S.O., Pacheco M.R., Lui J.F. \& Malheiros E.B. 2002. Morfometria dos túbulos seminíferos e ductos epididimários de cães e gatos provenientes de cirurgia de castração. Revta Biotemas 15(1):97-110. <https://dx.doi.org/10.5007/\%25x>

Leite F.L.G., Paula T.A.R., Matta S.L.P., Fonseca C.C., Neves M.T.D. \& Barros J.B.G. 2006. Cycle and duration of the seminiferous epithelium in puma (Puma concolor). Anim. Reprod. Sci. 91(3/4):307-316. <https://dx.doi. org/10.1016/j.anireprosci.2005.04.003>

Lents M.P., Barbosa L.P., Santana A.L.A., Pinheiro E.E.G., Mugabe L.C., Biscarde C.E.A. \& Souza R.S. 2018. Immunocastration of goats using anti gonadotrophin releasing hormone vaccine. Theriogenology 114:7-13. <https://dx.doi. org/10.1016/j.theriogenology.2018.03.013><PMid:29574307>

Lopes J.R.G., Santos J.R.S., Medeiros M.A., Campos E.M., Medeiros R.M.T. \& Riet-Correa F. 2017. Reproductive losses caused by the ingestion of Poincianella pyramidalis in sheep. Toxicon 138:98-101. <https://dx.doi. org/10.1016/j.toxicon.2017.08.020 ><PMid:28843661>

Maia G.N. 2012. Caatinga: árvores e arbustos e suas utilidades. $2^{\text {a }}$ ed. Printcolor, Fortaleza, p.159-169.

Marcelino S.A.C., Macêdo J.T.S.A., Reis S.D.S., Lacerda M.S.C., Silva A.R.S., Riet-Correa F., Pimentel L.A. \& Pedroso P.M.O. 2017. Malformações em pequenos ruminantes no semiárido da Bahia: aspectos epidemiológicos, clínico-patológicos e radiológicos. Pesq. Vet. Bras. 37(12):1437-1442. <https://dx.doi.org/10.1590/s0100-736x2017001200013>

Matias J.R., Silva F.F.S. \& Dantas B.F. 2017. Catingueira-verdadeira Poincianella pyramidalis [Tul.] L.P. Queiroz. Nota Técnica no 6, ABRATES, Londrina. Available at <http://www.alice.cnptia.embrapa.br> Accessed on Jun., 2019.

Mendonça Jr A.F., Braga A.P. \& Galvão R.J.D. 2008. Composição bromatológica, consumo e digestibilidade in vivo de dietas com diferentes níveis de feno de catingueira (Caesalpinea pyramidalis Tul.), fornecidas para ovinos SRD. Revta Biol. Ciênc. Terra 8(1):135-142.

Mohammed A.H.S., Kadium D.A.H \& Ebed A.K. 2011. Some morphometric and histological description of the seminiferous, striaghted and rete testis tubules in the testis of indogenous male goats (two years old). J. Vet. Med. Sci. 2(1):19-29.

Morais D.B., Barbosa L.P., Melo B.E.S., Matta S.L.P., Neves M.M., Balarini M.K. \& Rodrigues M.V. 2012. Microscopy and morphometry of tubular components of rabbit testis supplemented with royal jelly. Arq. Bras. Med. Vet. Zootec. 64(4):810-816. <https://dx.doi.org/10.1590/S0102-09352012000400004>

Queiroz A.C.P, Sousa M.S.A.S \& Sousa M.A.N. 2018. Atividade genotóxica de Cenostigma pyramidale (Tul.) Gagnon \& G.P. Lewis (Fabaceae) sob Allium cepa (Amaryllidaceae). III Congresso Nacional de Pesquisa e Ensino em Ciências, Campina Grande, PB. 12p. 
Reis S.D.S., Oliveira R.S., Marcelino S.A., Macêdo J.T.S., Riet-Correa F., Pimentel L.A. \& Pedroso P.M.O. 2016. Congenital malformations and other reproductive losses in goats due to poisoning by Poincianella pyramidalis (Tul.) L.P. Queiroz (=Caesalpinia pyramidalis Tul.). Toxicon 118:91-94. <https://dx.doi.org/10.1016/j.toxicon.2016.04.043><PMid:27125469>

Ribeiro P.H.C., Lima V., Urbano S.A., Menezes M.S., Tavares Neta M.D.L., Costa M.G., Aguiar E.M. \& Inácio J.G. 2020. Consumo e desempenho de cordeiros confinados alimentados com diferentes níveis de fibra em detergente neutro. Braz. J. Develop. 6(4):16964-16975. <https://dx.doi. org/10.34117/bjdv6n4-023>

Rodrigues M.H. 2010. Análise morfométrica e funcional do desenvolvimento testicular de caprinos da raça alpina criados em condições semi-intensivas. Doctoral Dissertation, Universidade Estadual do Norte Fluminense Darcy Ribeiro, Goytacazes, Rio de Janeiro. 159p.

Russell L.D., Ettlin R.A., Sinha Hikim A.P. \& Clegg E.D. 1993. Histological and histopathological evaluation of the testis. Int. J. Androl. 16(1):83-84. <https://dx.doi.org/10.1111/j.1365-2605.1993.tb01156.x>

Silva L.B., Santos F.A.R., Gasson P. \& Cutler D. 2009. Anatomia e densidade básica da madeira de Caesalpinia pyramidalis Tul. (Fabaceae), espécie endêmica da caatinga do Nordeste do Brasil. Acta Bot. Bras. 23(2):436-445. <https://dx.doi.org/10.1590/S0102-33062009000200015>

Souza L.E.B., Cruz J.F., Teixeira Neto M.R., Ferraz R.C.N. \& Cruz M.H.C.C. 2011. Puberty and sexual maturity in Anglo-Nubian male goats raised in semi- intensive system. Revta Bras. Zootec. 40(7):1533-1539. <https://dx.doi. org/10.1590/S1516-35982011000700019>

Souza M.F., Bezerra I.T.F., Barbosa F.M.S., Rocha V.C., Sousa M.S., Oliveira Neto T.S., Lacerda-Lucena P.B. \& Lucena R.B. 2018. Abortos, malformações congênitas e falhas reprodutivas espontâneas em caprinos causados na intoxicação pelas folhas da catingueira, Poincianella pyramidalis (sin. Caesalpinia pyramidalis). Pesq. Vet. Bras. 38(6):1051-1057. <https://dx.doi.org/10.1590/1678-5150-pvb-5243>

Urbano S.A., Ferreira M.A., Véras R.M.L., Azevedo P.S., Santos Filho H.B., Vasconcelos G.A. \& Oliveira J.P.F. 2015. Características de carcaça e composição tecidual de ovinos Santa Inês alimentados com manipueira. Revta Bras. Ciênc. Agrár. 10(3):466-472. <https://dx.doi.org/10.5039/ agraria.v10i3a4812>

Van Soest P.J. 1994. Nutritional Ecology of the Ruminant. 2nd ed. Cornell University Press, Ithaca, p.290-311.

Van Soest P.J., Robertson J.B. \& Lewis B.A. 1991. Methods for dietary fiber, neutral detergent fiber, and nonstarch polyssacharides in relation to animal nutrition. J. Dairy Sci. 74(10):3583-3597. <https://dx.doi.org/10.3168/ jds.S0022-0302(91)78551-2><PMid:1660498>

Vieira E.L, Carvalho F.F.R., Batista A.M.V., Ferreira R.L.C., Santos M.V.F., Lira M.A., Silva M.J. \& Silva E.M.B. 2005. Composição química de forrageiras e seletividade de bovinos em bosque de Sabiá (Mimosa caesalpiniifolia Benth.) nos períodos chuvoso e seco. Revta Bras. Zootec. 34(5):1505-1511. <https://dx.doi.org/10.1590/S1516-35982005000500010> 